\title{
CHALLENGES TO THE ADOPTION OF MODERN CROP BIOTECHNOLOGY: INSIGHTS FROM INDIAN AND MALAYSIAN GM REGULATORY FRAMEWORKS
}

\author{
JASDEEP KAUR DARSAN SINGH ${ }^{1}$, NURZATIL SHARLEEZA MAT JALALUDDIN ${ }^{1}$, \\ NEETI SANAN-MISHRA ${ }^{2}$ and JENNIFER ANN HARIKRISHNA ${ }^{1,3^{*}}$ \\ ${ }^{1}$ Centre for Research in Biotechnology for Agriculture (CEBAR), Level 3, \\ Research Management and Innovation Complex, University of Malaya, \\ Jalan Universiti, 50603 Kuala Lumpur, Malaysia \\ ${ }^{2}$ International Centre for Genetic Engineering and Biotechnology (ICGEB), \\ Aruna Asaf Ali Marg, New Delhi, Delhi 110067, India \\ ${ }^{3}$ Institute of Biological Sciences, Faculty of Science, University of Malaya, \\ Jalan Universiti, 50603 Kuala Lumpur, Malaysia \\ *E-mail: jennihari@um.edu.my
}

Accepted 30 November 2020, Published online 31 December 2020

\begin{abstract}
The emerging use of genetic engineering technology led to the establishment of the Cartagena Protocol on Biosafety in 2001. India and Malaysia are signatories to the Protocol, having established regulatory measures governing the use of biotechnological genetic modification including regulation of genetically engineered crops from research to open cultivation and post-market surveillance. India and Malaysia have developed biosafety policies that display some similarities but also many differences, consequently impacting the practicalities of applying the technology to development and deployment of new crop varieties. The objective of this paper is to compare biosafety policies and regulatory frameworks that India and Malaysia have in place for the use of modern biotechnology. We highlight the implications of imposing rigid requirements as well as lacking harmonized policies on the approval process and trade flows, identifying these as potential barriers to the optimal use of modern crop biotechnology. We also briefly discuss how current interpretations of Living Modified Organisms and Genetically Modified Organisms in India and Malaysia will influence the pace of crops developed from new plant breeding techniques and propose options to regulate these technologies based on experience from other countries.
\end{abstract}

Key words: Biosafety, regulation, GM crop, biotechnology, Malaysia, India

\section{INTRODUCTION}

First developed in 1973 (Cohen et al., 1973), genetic engineering has brought major advances in the process of manipulating GM genomes of microbes, plants and animals using recombinant DNA techniques. In most legislations, genetically engineered or Genetically Modified (GM) organisms are those produced by altering the genetic material in a way that does not occur naturally by mating and/or natural recombination. The use of genetic engineering allows genes to be transferred between related or non-related species into another organism. Such methods have been used to create several crops conferring specific desired traits, such as tolerance

\footnotetext{
* To whom correspondence should be addressed.
}

or resistance towards plant pests and pathogens, resilience to drought and salinity stresses as well as improved nutritional values (ISAAA, 2018). The number of GM crops has grown exponentially since the first GM crop, the Flavr Savr tomato was released commercially in 1994 and sold in the USA up to 1997. To date, more than 10 different crop plants have been planted worldwide with various GM traits, the most extensively grown so far being soybean, cotton, maize and canola (ISAAA, 2018). As of 2017, 24 countries were growing GM crops on 189.8 million hectares, creating an incredible supply for an industry that is now worth US $\$ 17.2$ billion (ISAAA, 2018).

Despite the many benefits, the use of genetic engineering including for developing new varieties of crops was from the beginning considered from a 
perspective of potential risks that the technology could pose to human health and the environment. This concern, largely initiated by scientists within the field, led to a series of meetings between representatives from the concerned nations between 1995 and 2000, and in 2001 a legally binding agreement governing the movements of living modified organisms (LMOs) resulting from modern biotechnologies, was made between 103 countries (Secretariat of the Convention on Biological Diversity, 2012). The agreement known as The Cartagena Protocol on Biosafety, which came into force in September 2003, was established through the provision of a comprehensive set of policies and measures, spanning the entire development process from $R \& D$ to commercial release and post-release monitoring stages (Secretariat of the Convention on Biological Diversity \& United Nations Environment Programme, 2003). Although the Protocol established a certain level of harmonized biosafety measures, there remain significant differences in the interpretation of the instrument between countries and the mechanisms by which LMOs are regulated and approved (Jones, 2015). As such, biosafety policies such as socioeconomic considerations, public participation in decision-making, low-level presence (LLP), GM food labelling as well as the definitions of LMOs and GM organisms (GMOs) may be different from one country to another (Escaler et al., 2012). India and Malaysia are both signatories of The Cartagena Protocol on Biosafety in 2001. Each country has developed legislation and guidelines for the development and commercial release of genetically engineered crops, yet of the two, only India has such crops grown commercially at this time.

The primary objective of this study was to make a comparison between the biosafety regulations of India and Malaysia, discuss the components that are significantly different, and comment on how such differences may impact the application of the technology. This study found that the lack of harmonized standards, such as for low-level presence (LLP) and GM labelling, could have economic implications in food trade. Furthermore, this study also revealed disagreements in defining the scope of LMOs and GMOs in India and Malaysia that could influence the pace of crops developed from new plant breeding techniques (NPBTs). As the way forward, it is proposed for the national biosafety regulations to be reviewed, taking experiences from other countries into account.

\section{Biosafety regulations in India and Malaysia}

India was one of the first nations to formalize biosafety legislation, having its guidelines developed before ratifying the Cartagena Protocol, under the direction of The Environment Protection
Act 1986 (The Environment Protection Act, India, 1986) and Rules for the Manufacture, Use, Import, Export and Storage of Hazardous Micro-Organisms/ Genetically Engineered Organisms or Cells 1989 (Ministry of Environment and Forests, India, 1989). Since the introduction of biosafety laws, India has granted 6 approvals for commercial cultivation of GM crops and issued more than 60 approvals for cultivation of GM crops in confined field trials (Shukla et al., 2018). Malaysia, on the other hand, introduced The Biosafety Act 2007 (Laws of Malaysia, 2007) after signing the Cartagena Protocol, and has granted only 3 approvals for confined field trials, while none have been issued for environmental release (Department of Biosafety, 2019). Other visible outcomes after signing the Protocol are the inclusion of several policies such as socio-economic considerations, public participation in decision-making, low-level presence (LLP) and GM food labelling into national legislation. Both Indian and Malaysian biosafety guidelines display some commonalities and differences with regards to the described policies as well as the scope for LMOs and GMOs (Table 1).

\section{Socio-economic considerations}

Indian biosafety law does not include any formal mandatory requirement for socio-economic studies to be included in the decision-making process in the country. Nonetheless, there may be some circumstances in which socio-economic surveys are needed, and in this regard, the regulatory authority, which is the Genetic Engineering Appraisal Committee (GEAC), has the flexibility to request for such studies to be conducted. In fact, in past years, such requests were made in respect of applications for field release of Bacillus thuringiensis (Bt) Cotton (Ministry of Agriculture, 2016) and Bt Brinjal (Sharma, 2008). The case studies were undertaken to evaluate the economic impacts of transgenic crops over existing varieties in the designated states or districts, and the studies will be considered by GEAC when making decisions for a GM crop approval.

In Malaysia, Section 35 of the Biosafety Act 2007 clarifies that socio-economic assessments are not mandatory for regulatory decision-making in Malaysia (Laws of Malaysia, 2007). However, conducting such studies may be useful to identify the changes that may occur on social and economic aspects of the communities that are likely to be affected by the introduction of the GM product as well as to delineate the possible effects from the use or release of the GM product on ethical, religious and cultural values of communities (Ramatha \& Andrew, 2012). It also has been suggested that in Malaysia, socio-economic considerations may 
Table 1. Similarities and differences between Indian and Malaysian biosafety regulations

\begin{tabular}{|c|c|c|}
\hline Biosafety policies & India & Malaysia \\
\hline $\begin{array}{l}\text { Laws and } \\
\text { regulations }\end{array}$ & $\begin{array}{l}\text { The Environment Protection Act } 1986 \\
\text { Rules for the Manufacture, Use, Import, Export and } \\
\text { Storage of Hazardous Microorganisms / } \\
\text { Genetically Engineered Organisms or Cells } 1989\end{array}$ & The Biosafety Act 2007 \\
\hline $\begin{array}{l}\text { Socio-economic } \\
\text { considerations }\end{array}$ & $\begin{array}{l}\text { Similarity: } \\
\text { Non-mandatory for the regulatory decision-making process } \\
\text { Difference: } \\
\text { Scope focuses on the economic aspect only }\end{array}$ & $\begin{array}{l}\text { Scope focuses on economic and } \\
\text { social aspects }\end{array}$ \\
\hline $\begin{array}{l}\text { Public } \\
\text { participation }\end{array}$ & $\begin{array}{l}\text { Similarity: } \\
\text { Requires public engagement in the approval process, } \\
\text { for confined field trial, field trial and commercial release } \\
\text { Difference: } \\
\text { Public meetings were carried out for applications } \\
\text { involving the environmental release of GM food }\end{array}$ & $\begin{array}{l}\text { Public meetings were carried out for } \\
\text { an application involving the confined } \\
\text { field trial assessment for GM mosquito }\end{array}$ \\
\hline $\begin{array}{l}\text { Low-level } \\
\text { presence (LLP) }\end{array}$ & $\begin{array}{l}\text { Similarity: } \\
\text { Both adopt zero-tolerance policy towards LLP and } \\
\text { no incident has been reported in the countries so far } \\
\text { Difference: } \\
\text { None }\end{array}$ & None \\
\hline $\begin{array}{l}\text { GM food } \\
\text { labelling }\end{array}$ & $\begin{array}{l}\text { Similarity: } \\
\text { Mandatory labelling } \\
\text { Difference: } \\
\text { Lacking in proper scope and guidelines (For example, } \\
\text { the minimum threshold levels and the coverage) }\end{array}$ & Clearly defined scope and guidelines \\
\hline $\begin{array}{l}\text { Definition } \\
\text { of GMO }\end{array}$ & $\begin{array}{l}\text { Similarity: } \\
\text { Process-based approach } \\
\text { Difference: } \\
\text { Uses the terms 'gene technology' and } \\
\text { 'genetic engineering' to define a genetically } \\
\text { modified organism }\end{array}$ & $\begin{array}{l}\text { Uses the terms 'living organism, 'living } \\
\text { modified organism' and 'modern } \\
\text { biotechnology' to define a genetically } \\
\text { modified organism }\end{array}$ \\
\hline
\end{tabular}

become crucial if a GM product that carries novel traits such as high productivity and high added value, belongs to a primary commodity like rubber, rice or oil palm (Ramatha \& Andrew, 2012). This was based on the scenario where smallholders producing non-GM materials are competing with higher valued GM products, with the possibility that their income streams will be severely affected (Ramatha \& Andrew, 2012). However, such a case can also easily arise from non-GM elite crop varieties, so this would be best considered outside of the biosafety context, as a separate socioeconomic matter. Nonetheless, thus far, the National Biosafety Board of Malaysia has only issued approvals for the import of GM grains and products that are not normally grown in Malaysia, which makes the probability for any socio-economic problems particular to GM crops, relatively low (Ramatha \& Andrew, 2012). There is a slight difference in the aspects that need to be taken into account for socio-economic studies between India and Malaysia. Indian regulatory authorities emphasize only on economic impacts from the introduction of GM crops while Malaysian authorities regard both social and economic impacts as the primary concerns when undertaking socioeconomic studies. The inconsistencies in the scope of socio-economic countries will increase the cost of compliance associated with conducting such studies and potentially delay the approval process.

\section{Public participation}

Commitment to public participation in the administrative decision-making process for GM product approvals becomes an explicit feature of the biosafety regulatory landscape in most countries including India and Malaysia. Public engagement is facilitated by public announcements for all GM applications and opportunities for public comments before a decision is made. These elements of openness and transparency are embedded to build public trust in the regulatory system. In India for example, the particulars of the applicant and necessary details that are not labelled as confidential for every application for approval of a confined field trial, field trial or commercial release of a GM crop shall be disclosed for public view (Ministry of Environment and Forests, 2010). The public consultation period runs for 30 days and announcements are made through various communication modes such as press releases, reports 
and data material held in electronic forms (Ministry of Environment and Forests, 2010). Indian regulatory authorities also organized open meetings that extend to a wide range of stakeholders, such as individual farmers and farmer organizations, consumer groups, scientists and state agriculture department officials (Ministry of Environment and Forests, 2010). However, not all outcomes from consultative meetings were reported as favouring GM crops. Some of them have put undue pressure on the Indian government, which have led to moratoria on the environmental release of Bt Brinjal (Kumar et al., 2011) and GM mustard (Jayaraman, 2017).

Similar to India, the Malaysian government has required public participation and invites citizens to share their views and comments on an application for approval, approval granted or notification. In soliciting public inputs, the Malaysian National Biosafety Board publishes a report that provides an overall background of the application, together with essential information related to the assessment of the risks of the application. A public consultation will be sought in 30 days for each proposal and all written submissions of comments from the public will be taken into consideration before a regulatory decision is made (Department of Biosafety, 2013). A standard notice will be advertised in four relevant newspapers (One newspaper in each of the four main language media of Bahasa Melayu, English, Tamil and Mandarin) with nationwide coverage, as well as on the biosafety website (Department of Biosafety, 2013). Complying with the provision under Section 60 of the Biosafety Act 2007, the notice must disclose all information, which has not been granted confidentiality, related to any application for regulatory approval, approval granted, or notification (Laws of Malaysia, 2007). Although the countries need to involve public participation to gain trust in biosafety decision-making, the implementation of an effective public consultation process can be counterproductive, especially if there are insufficient resources to conduct the consultation process and lacking proper guidelines to avoid biases and misunderstandings of the technology (Quinland et al., 2016). As with socioeconomic considerations, the absence of comprehensive guidelines will result in additional regulatory costs and delays in approving GM crops.

\section{Low-level presence (LLP)}

An issue of concern for a biosafety regulatory system is the approach that a country uses when addressing the adventitious or low-level presence (LLP) situations. LLP is defined as the unintended presence of low amounts of authorised GM events being produced in a country but not approved in the importing country (Kalaitzandonakes, 2011). LLP situations may also occur due to different policies on LLP between trading countries, as the variations in authorization procedures, and approval timeline in agricultural commodity trading countries may create international trade risks particularly in countries that are yet to adopt approaches to dealing with LLP situations (de Faria \& Wieck, 2015). In some instances, LLP may arise when developers of the authorized GM crop do not seek approval in potential importing countries or due to inadvertent contamination by unapproved GM crops in the commercial crop supply (de Faria \& Wieck, 2015). Experience with previous LLP incidents in shipments from the USA to the EU, for example, Herculex maize, LibertyLink rice and RoundupReady 2 Soybeans demonstrated that the problem of LLP could be real (Stein \& Rodríguez-Cerezo, 2010; Smyth, 2017). Since EU regulations follow a "zero tolerance" policy, these shipments were denied from entering EU, resulting in income losses to exporters and GM producers (Carter \& Smith, 2007; Ryan \& Smyth, 2012), and further causing a significant drop in US exports since the incidents (Smyth, 2017).

India (Singh, 2017) and Malaysia (Andrew et al., 2017) also adopt a zero-tolerance policy towards LLP, highlighting that any contamination by unauthorized GM ingredients detected in imported food or feed material will not be allowed to cross the border. The zero-tolerance policy has been viewed as unrealistic within the current trend of an increasing number of new GM products in the pipeline in developed and developing countries. It is nearly impossible to avoid all contact between GM and non-GM products once a GM crop has been released, as trace amounts of GM could become mixed with other crops at various development stages, or during harvest, transport, processing, packing, and storage (Kalaitzandonakes, 2011). Furthermore, the GM crop might move freely between states, provinces and districts within a large nation, especially if the GM is not regulated or different rules are enforced. Although no incident of LLP has been reported in Malaysia (Andrew et al., 2017) and India (Atisi, 2014), it is not guaranteed that LLP would not occur in the future. Therefore, it is still important for both countries to consider replacing zero-tolerance policies with a defined non-zero tolerance level, with the levels are within the range of detection, compatible with other tolerance levels (Kalaitzandonakes, 2011) and harmonized with major trade partners (Kruger \& Le Buanec, 2008).

\section{GM food labelling}

Another key issue for the regulation of GM products in both India and Malaysia is the labelling policy in the countries. The labelling policy has become a subject of debate, particularly due to the concerns of traceability (Miraglia et al., 2014; 
Andrew et al., 2017), enforcement of post-market surveillance, and the added cost incurred in establishing a segregation system that separates GM and non-GM products along the food supply chain (Smyth \& Phillips, 2003). The Indian government has legislated a labelling policy that would require all transgenic-derived foods to be labelled, to inform consumers that these food products contain ingredients derived from genetically modified crops or animals. The labelling policy was made mandatory in 2012 by the Department of Consumer Affairs, which has also issued a notification G.S.R 427(E) stating that every package containing genetically modified food must display the abbreviation "GM" (Legal Metrology (Packaged Commodities) Amendment Rules, India, 2012). However, it was noted that the proposed policy may create confusion as the letters "GM" may be interpreted as an abbreviation for weight measurement, "gram" (The Daily Mail, 2013). The policy was also criticized, on the basis that the scope was not well defined, in particular the specifics of the threshold level for which food would be regarded as a GM product, as well as the product types that would require mandatory labelling, meaning that changes are needed before the law can be enforced effectively (Bansal, 2013).

In an attempt to address the gap in the current GM food labelling law in India, The Food Safety and Standards Authority of India has recently released a draft notification on GM food labelling. The draft notice highlighted that food products shall be labelled as "Contains GMO/Ingredients derived from GMO" if the product contains three GM ingredients combined above $5 \%$ by weight or volume in a packaged food product (Food Safety and Standards Authority of India, 2018). The Food Safety and Standards Authority of India is now waiting for comments from stakeholders before the draft will form the Food Safety and Standards (Labelling and Display) Regulations, 2018. On another note, the GM food labelling policy received mixed views on whether a voluntary or a mandatory mechanism would better suit India. One of the opinions came from the President of the Indian National Science Academy, Dr. M. Vijayan who stated his view that a voluntary labelling policy would be more practical in India compared to mandatory labelling. He explicitly mentioned that it is more difficult to implement mandatory labelling in India because of the structure of the retail market in the country that will complicate the monitoring task (Ramesh, 2016).

Likewise, Malaysia has established regulations that set out specific labelling requirements for GM products. The regulations were enacted in 2010 under the Food Regulations 1985 (Ministry of Health Malaysia, 2010) and the Food Act 1983
(Laws of Malaysia, 2007), namely, Regulations 11(3A), 11(6), and 11(7). These regulations, which came into force in 2014, were legislated in accordance to the Section 61 of the Biosafety Act 2007, which stipulates that all LMOs, food containing LMOs and products derived thereof have to be identified and labelled (Laws of Malaysia, 2007). Based on Regulation 11 (3A), $11(6)$ and 11(7), the labelling requirement is only applicable to the three main GM ingredients in the ingredient list. Nonetheless, labelling is not compulsory for food containing less than 3\% GM content, given that the inclusion of GM content is unintentional and technically unavoidable (Ministry of Health Malaysia, 2010). There are several exemptions to the labelling requirement, for example, highly refined foods, foods from animals fed with GM animal feed, and foods produced with GM enzymes. However, only those events that received approval from the NBB can be considered as the permitted events for foods and food ingredients obtained through modern biotechnology (Ministry of Health Malaysia, 2010). The established prerequisite, which necessitates every single GM crop event used throughout the supply chain must be approved by NBB, adds a layer of complexity to monitoring and enforcement mechanisms for GM food labelling. It is indeed a great challenge to effectively trace unauthorised GM crops, especially in the absence of trustable documentation systems, the limited capacity of current detection methods, which includes DNAbased detection (such as real-time quantitative PCR, loop-mediated isothermal amplification PCR, and multiplex PCR) and antibody-based detection (reviewed in Kamle et al., 2017), as well as the lack of availability of specific reference materials for each GM product (Miraglia et al., 2014; Andrew et al., 2017). While the labelling law is in force, it has yet to be rigorously applied in the country, as commented by a former Director of the Centre of Excellence for Biodiversity, University of Malaya, Dr. Gurdial Singh, who mentioned that there is as yet no regulatory oversight body responsible for the enforcement in regards to industry guidelines for the prevention of cross-contamination between GM and non-GM food crops (Nijar, 2017).

Based on the current situations in India and Malaysia, the divergence in GM labelling policy of the countries is particularly evident with regards to the minimum threshold levels of GM ingredients as well as the coverage that requires GM labelling. In addition to different rules for GM labelling between the countries, the various degree of enforcement and clarity of the rules in both India and Malaysia may affect future production costs and global trade of GM products. 


\section{Definition of genetically engineered cells and organisms, LMOs and GMOs}

The Indian "Rules for the Manufacture, Use/Import/Export and Storage of Hazardous Microorganisms/ Genetically Engineered Organisms or Cells 1989 uses the term 'genetically engineered organisms' when addressing LMOs and GMOs. India further defines the terms by providing definitions for gene technology and genetic engineering in its biosafety legislation (Ministry of Environment and Forests, India 1989). On the other hand, in Malaysia, the term LMO and GMO are used interchangeably. According to the Biosafety Act 2007, an LMO is defined by the interpretations of the terms living organism, living modified organism, and modern biotechnology (Laws of Malaysia, 2007). The definitions suggest that a genetically modified organism must have a novel combination of genetic material and will be regulated if the process by which it was produced involved modern biotechnology techniques, in other words, the definition depends on the process by which the cell or organism was modified.

Although a process-based approach has been employed to regulate GM crops, the practicality of using the "process" element as the regulatory trigger when dealing with new plant breeding techniques
(NPBTs) is of great concerns among scientists and regulators. Unlike traditional GM technologies that involve the insertion of foreign DNA into a species, NPBTs use regulatory RNA molecules and/or sitespecific DNA-cutting enzymes to obtain the desired trait (Sprink et al., 2016). Recent dialogues and discussions have described issues when regulating NPBT techniques within current regulatory frameworks, particularly if modifications result in organisms that are biologically indistinguishable to those obtained by conventional breeding or by classical mutagenesis (Huang, 2016). The consensus among the experts is that products resulting from NPBTs that does not introduce foreign DNA will pose no increased risk (reviewed in Shao et al., 2018) and will not have traceability problems (reviewed in Sprink et al., 2016), suggesting that having to go through regulatory procedures is a waste of resources. To date, several governments have revised their biosafety legislation (Table 2), while several others are actively reviewing their legislation and for the remainder, legislation remains uncertain. The general observation that can be drawn from recent regulatory decisions for NPBTs is that the majority of governments that have reviewed their biosafety legislations have chosen to regulate NPBT products based on the final traits (i.e. product-based), rather

Table 2. Recent rulings on non-transformative RNAi and gene-editing techniques

\begin{tabular}{|c|c|c|c|}
\hline Country & NBPT techniques & Rulings & Reference \\
\hline \multirow[t]{2}{*}{ Australia } & $\begin{array}{l}\text { Non-transformative } \\
\text { RNAi }\end{array}$ & $\begin{array}{l}\text { Exogenous RNAi techniques are not gene } \\
\text { technology, as long as no alteration of the } \\
\text { organism's genome occurs, and the RNA cannot } \\
\text { be translated into a polypeptide, and cannot give } \\
\text { rise to an infectious agent }\end{array}$ & OGTR, 2017 \\
\hline & Genome-editing & Currently under review & $\begin{array}{l}\text { Personal } \\
\text { communication }\end{array}$ \\
\hline Canada & $\begin{array}{l}\text { Non-transformative } \\
\text { RNAi and } \\
\text { genome-editing }\end{array}$ & $\begin{array}{l}\text { No specific legislations have been made, but } \\
\text { Canada has a product-based biosafety system } \\
\text { that considers trait novelty as the regulatory } \\
\text { trigger, regardless of methods used }\end{array}$ & $\begin{array}{l}\text { Canadian Food } \\
\text { Inspection Agency, } \\
2018\end{array}$ \\
\hline Europe & Genome-editing & $\begin{array}{l}\text { Genome-edited crops will be regulated under the } \\
\text { GMO directive }\end{array}$ & Wight, 2018 \\
\hline \multirow[t]{2}{*}{ New Zealand } & $\begin{array}{l}\text { Non-transformative } \\
\text { RNAi }\end{array}$ & $\begin{array}{l}\text { dsRNA-treated eukaryotic cells are out of the scope } \\
\text { of new organisms (also defined as genetically } \\
\text { modified organisms) because there is limited } \\
\text { evidence suggesting inheritable transmission of } \\
\text { dsRNAs in the host organism, and the introduction } \\
\text { of dsRNAs causes only transient gene suppression }\end{array}$ & $\begin{array}{l}\text { The Environmental } \\
\text { Protection Authority } \\
\text { of New Zealand, } \\
2018\end{array}$ \\
\hline & Genome-editing & $\begin{array}{l}\text { All products of gene editing will be regulated } \\
\text { as GMOs }\end{array}$ & Fritsche et al., 2018 \\
\hline \multirow[t]{2}{*}{ USA } & $\begin{array}{l}\text { Non-transformative } \\
\text { RNAi }\end{array}$ & $\begin{array}{l}\text { The use of dsRNA as biopesticides will be } \\
\text { regulated as chemical pesticides }\end{array}$ & FIFRA, 2013 \\
\hline & Genome-editing & $\begin{array}{l}\text { United States Department of Agriculture has } \\
\text { ruled that genome-edited plants are not GMOs }\end{array}$ & Waltz, 2018 \\
\hline $\begin{array}{l}\text { Argentina, Chile, } \\
\text { Brazil and } \\
\text { Colombia }\end{array}$ & Genome-editing & $\begin{array}{l}\text { Gene-edited crops will not be subject to } \\
\text { GMO regulation is no transgene is inserted }\end{array}$ & $\begin{array}{l}\text { Eckerstorfer, 2019; } \\
\text { Metje-Sprink, } 2019\end{array}$ \\
\hline
\end{tabular}


than the methods used (process-based). Regulating modern biotechnology products based on final risks will be a way forward for countries with a processbased biosafety regulation, such as India and Malaysia, which will struggle to monitor products of NPBTs especially those that are similar to conventionally-bred or mutagenic counterparts.

\section{CONCLUSION}

As GM crops and their products are becoming more widely traded globally, it is important to consider re-evaluating current regulatory measures to ensure that current policies are more harmonized and will be less disruptive to future trade flows. This is exceptionally important for both India and Malaysia, as these countries have active trade agreements and activities (Ministry of International Trade and Industry, 2015). In this regard, a critical challenge for regulatory authorities in the countries is to consider revising national policies towards a more harmonized structure and to develop practical policies, such as for LLP and GM labelling, which could control impacts of an increase in food prices. Another challenge to biosafety regulators is to reevaluate and harmonize the current scope and interpretations of genetically engineered organisms or cells, LMOs and GMOs for applications from NPBTs. Periodic discussions, workshops and meetings within the countries as well as with other countries should be encouraged to provide clarity and ensure harmonisation when regulating these new technologies.

\section{ACKNOWLEDGEMENTS}

This work was partially supported by the Malaysian Ministry of Higher Education for the Malaysian Research University Network- Long Term Research Grant Scheme (MRUN-LRGS). Jasdeep Kaur Darsan Singh was supported by MyPhD Scholarship under MyBrain 15 program (Ministry of Education, Malaysia) and an Arturo Falaschi Fellowship (International Centre For Genetic Engineering And Biotechnology, ICGEB). Dr. Nurzatil Sharleeza Mat Jalaluddin was supported by University of Malaya Post-Doctoral Research Fellowship (PDRF) and CEBAR Research University Grants (RU006-2017 and RU006-2018).

\section{REFERENCES}

Andrew, J., Ismail, N.W. \& Djama, M. 2018. An overview of genetically modified crop governance, issues and challenges in Malaysia. Journal of the Science Food and Agriculture, 98(1): 12-17.

Atisi, C. 2014. Low levels of genetically modified crops in international food and feed trade: FAO international survey and economic analysis. Food and Agriculture Organization of the United Nations, Rome.

Bansal, S. 2013. Labelling policy for genetically modified foods in India. Economic Political Weekly, 48(34): 15-7.

Canadian Food Inspection Agency. 2016. Regulating agricultural biotechnology in Canada: An overview [WWW Document]. URL http://www.inspection.gc.ca/plants/plantswith-novel-traits/general-public/overview/ eng/ $1338187581090 / 1338188593891$ (accessed 4.9.2019).

Carter, C.A. \& Smith, A.W. 2007. Estimating the market effect of a food scare: The case of genetically modified StarLink corn. Review of Economics and Statistics, 89(3): 522-33.

Cohen, S.N., Chang, A.C., Boyer, H.W. \& Helling, R.B. 1973. Construction of biologically functional bacterial plasmids in vitro. Proceedings of the National Academy of Sciences of the United States of America, 70(11): 3240-3244.

de-Faria, R.N. \& Wieck, C. 2015. Empirical evidence on the trade impact of asynchronous regulatory approval of new GMO events. Food Policy, 53: 22-32.

Department of Biosafety, Ministry of Natural Resources and Environment Malaysia. 2013. Guidelines in Making Public Announcement for Application for Approval (Release Activities). Department of Biosafety, Putrajaya.

Department of Biosafety, Ministry of Water, Land and Natural Resources Malaysia. 2019. Field trial: Approval for release [WWW Document] URL http://www.biosafety.nre.gov.my/country_ decision/app_ft.shtml (accessed 4.9.2019).

Eckerstorfer, M.F., Engelhard, M. \& Heissenberger, A. 2019. Plants developed by new genetic modification techniques-Comparison of existing regulatory frameworks in the EU and non-EU countries. Frontiers in Bioengineering and Biotechnology, 7: 26. 
Escaler, M., Teng, P.P.S. \& Power, A.D. 2012. Challenges of harmonization of agricultural biotechnology regulatory systems across APEC economies. Biosafety, 1(3): 1000101.

Federal Insecticide, Fungicide, and Rodenticide Act (FIFRA). 2013. White paper on RNAi technology as a pesticide: Problem formulation for human health and ecological risk assessment [WWW Document]. URL http://www. thecre.com/premium/wp-content/uploads/2012/ 04/RNAi-White-Paper.pdf (accessed 4.9.2019).

Food Safety and Standards Authority of India. 2018. Notice calling for suggestions, views, comments etc. from stakeholders on the draft Food Safety and Standards (Labelling and Display) Regulations 2018. Food Safety and Standards Authority of India, New Delhi.

Fritsche, S., Poovaiah, C., MacRae, E. \& Thorlby, G. 2018. A New Zealand perspective on the application and regulation of gene editing. Frontiers in Plant Science, 9: 1323.

Huang, S., Weigel, D., Beachy, R.N. \& Jiayang, L. 2016. A proposed regulatory framework for genome-edited crops. Nature Genetics, 48: 109111.

ISAAA, 2018. Pocket K No. 16: Biotech crop highlights in 2018 [WWW Document]. URL http://www.isaaa.org/resources/publications/ pocketk/16/ (accessed 4.9.2019).

Jayaraman, K. 2017. Activists bury India's GM mustard hopes. Nature Biotechnology, 35: 1124.

Jones, H.D. 2015. Future of breeding by genome editing is in the hands of regulators. GM Crops \& Food: Biotechnology in Agriculture and the Food Chain, 6(4): 223-32.

Kalaitzandonakes, N. 2011. The economic impacts of asynchronous authorizations and low level presence: An overview. Position paper [WWW Document]. URL https://www.agritrade.org/ Publications/documents/LLPOverview.pdf (accessed 4.9.2019).

Kamle, M., Kumar, P., Patra, J.K. \& Bajpai, V.K. 2017. Current perspectives on genetically modified crops and detection methods. 3 Biotech, 7: 219.

Kruger, R. \& Le-Buanec, B. 2008. Action needed to harmonize regulation of low-level presence of biotech traits. Nature Biotechnology, 26(2): 161-2.

Kumar, S., Misra, A., Verma, A.K., Roy, R., Tripathi, A., Ansari, K.M., Das, M. \& Dwivedi, P.D. 2011. Bt Brinjal in India: A long way to go. $G M$ Crops, 2(2): 92-8.

Laws of Malaysia, Act 678, Biosafety Act 2007 (Aug. 28, 2007).
Legal Metrology (Packaged Commodities) Amendment Rules, Notification G.S.R.427(E). 2012.

Metje-sprink, J., Menz, J., Modrzejewski, D. \& Sprink, T. 2018. DNA-free genome editing: Past, present and future. Frontiers in Plant Science, 9: 1957.

Ministry of Agriculture, Department of Agriculture and Cooperation (Crop Division), India. 2016. Impact Evaluation \& Socio Economic Study of Bt Cotton. Global AgriSystem Private Limited, New Delhi.

Ministry of Environment and Forests, India. 2010. Decision on commercialisation of Bt Brinjal [WWW Document]. URL http://www.moef. nic.in/downloads/public-information/ minister_REPORT.pdf; (accessed 4.9.2019).

Ministry of Environment and Forests, India. 1989. Rules for the manufacture, use/import/export and storage of hazardous microorganisms/ genetically engineered organisms or cells [WWW Document]. URL http://www.geacindia. gov.in/resource-documents/biosafetyregulations/acts-and-rules/Rules-for-themanufacture-use-import-export-and-storage1989.pdf; (accessed 4.9.2019).

Ministry of Health Malaysia. 2010. Guidelines on labelling of foods and food ingredients obtained through modern biotechnology (Regulations 11(3a), 11(6) and 11(7), Food Regulations 1985). Ministry of Health Malaysia, Putrajaya.

Ministry of International Trade and Industry, Malaysia. 2015. Malaysia's free trade agreements: Malaysia - India [WWW Document]. URL http://fta.miti.gov.my/index.php/pages/ view/malaysia-india? $\mathrm{mid}=44$; $($ accessed 4.9 . 2019).

Miraglia, M., Berdal, K.G., Brera, C., Corbisier, P., Holst-Jensen, A., Kok, E.J., Marvin, H.J., Schimmel, H., Rentsch, J., van-Rie, J.P. \& Zagon, J. 2004. Detection and traceability of genetically modified organisms in the food production chain. Food and Chemical Toxicology, 42(7): 1157-80.

Nijar, G.S. 2017. Genetically modified food safe? [WWW Document]. The Sun Daily. URL https:/ /www.thesundaily.my/archive/geneticallymodified-food-safe-XTARCH452667 (accessed 4.9.2019).

Office of the Gene Technology Regulator (OGTR). 2017. Updating Gene Technology Regulation in Australia: Regulation impact statement for consultation 2017 [WWW Document]. URL http://www.ogtr.gov.au/internet/ogtr/ publishing.nsf/content/39DB72B3BB9AA790 CA25823B00812B73/\$File/Regulation $\% 20$ Impact $\% 20$ Statement $\% 20$ for $\% 20$ consultation. pdf; (accessed 2.2.2019). 
Quinland, M.M., Smith, J., Layton, R., Keese, P., Agbagala, M.L.U., Palacpac, M.B. \& Ball, L. 2016. Experiences in engaging the public on biotechnology advances and regulation. Frontiers in Bioengineering and Biotechno$\log y, 4: 3$

Ramatha, L. \& Andrew, J. 2012. Socio-economic aspects in decision-making in the context of the Biosafety Protocol: Malaysia's experience and case studies. Asian Biotechnology Development Review, 14(3): 19-30.

Ramesh, J. 2016. Bt Brinjal: Note by Ministry of Environment and Forests [WWW Document]. The Hindu. URL http://www.thehindu.com/ news/national/Bt-Brinjal-Note-by-Ministry-ofEnvironment-and Forests/article16578296.ece; (accessed 4.9.2019).

Ryan, C.D. \& Smyth, S.J. 2012. Economic implications of low-level presence in a zerotolerance European import market: The case of Canadian Triffid Flax. AgBioForum, 15(1): 3.

Secretariat of the Convention on Biological Diversity. 2012. About the protocol [WWW Document]. URL http://bch.cbd.int/protocol/ background/\#history/; (accessed 4.9.2019).

Secretariat of the Convention on Biological Diversity \& United Nations Environment Programme. 2003. Biosafety and the environment: An introduction to the Cartagena Protocol on biosafety [WWW Document]. URL https:// www.cbd.int/doc/press/presskits/bs/cpbs-unepcbd-en.pdf/; (accessed 4.9.2019).

Shao, Q., Punt, M. \& Wesseler, J. 2018. New plant breeding techniques under food security pressure and lobbying. Frontiers in Plant Science, 9: 1324.

Sharma, A.B. 2008. GEAC calls for socio-economic survey of Bt brinjal [WWW Document]. The Financial Express. URL http://www.financial express.com/news/GEAC-calls-for-socioeconomic-survey-ofBt-brinjal/313798/; (accessed 4.9.2019).

Shukla, M., Al-Busaidi, K.T., Trivedi, M. \& Tiwari, R.K. 2018. Status of research, regulations and challenges for genetically modified crops in India. GM Crops \& Food: Biotechnology in Agriculture and the Food Chain, 9(4): 173-188.
Singh, S.K. 2017. India: Agricultural biotechnology annual report [WWW Document]. USDA Foreign Agricultural Service. URL https:// gain.fas.usda.gov/Recent $\% 20$ GAIN\%20 Publications/Agricultural\%20Biotechnology \%20Annual_New\%20Delhi_India_11-28-2017. pdf; (accessed 4.9.2019).

Smyth, S. \& Phillips, P.B.W. 2003. Labelling to manage marketing of GM foods. Trends in Biotechnology, 21(9): 389-393.

Smyth, S.J. 2017. Genetically modified crops, regulatory delays, and international trade. Food and Energy Security, 6(2): 78-86.

Sprink, T., Eriksson, D., Schiemann, J. \& Hartung, F. 2016. Regulatory hurdles for genome editing: process- vs. product-based approaches in different regulatory contexts. Plant Cell Reports, 35(7): 1493-1506.

Stein, A.J. \& Rodríguez-Cerezo, E. 2010. Low-level presence of new GM crops: An issue on the rise for countries where they lack approval. AgBioForum, 13(2): 8

The Daily Mail. 2013. GM food labelling comes into force in India but it is not explicit [WWW Document]. URL http://transmissionsmedia. com/gm-food-labelling-comes-into-force-inindia-but-it-is-not-explicit/; (accessed 4.9.2019).

The Environment Protection Act, 1986, No. 29 of 1986 (May 23. 1986).

The Environmental Protection Authority of New Zealand. 2018. Determining whether eukaryotic cell lines treated with double-stranded RNA are genetically modified organisms [WWW Document]. URL https://www.epa.govt.nz/ assets/FileAPI/hsno-ar/APP203395/APP203395EPA-Advice-Document-FINAL.pdf; (accessed 4.9.2019).

Waltz, E. 2018. With a free pass, CRISPR-edited plants reach market in record time. Nature Biotechnology, 36: 6-7.

Wight, A.J. 2018. Strict EU ruling on gene-edited crops squeezes science. Nature, 563: 15-16. 
